\title{
Role and Place of Religious Consciousness in Culture Formation
}

\author{
Ekaterina Bobyreva $^{1 *}$, Marina Zheltuhina ${ }^{1}$, Olga Dmitrieva $^{2}$, and Maryana Busygina ${ }^{3}$ \\ 1 , English Language Theory Department, Volgograd State Social Pedagogical University400066 Lenin Av. 27, Volgograd, Russia \\ ${ }^{2}$ Russian as a Foreign Language Department, Volgograd State Social Pedagogical University, 400066 Lenin Av. 27, Volgograd, Russia \\ ${ }^{3}$ English Language and Methods of its Teaching Department, Volgograd State Social Pedagogical University, 400066 Lenin Av. 27, \\ Volgograd, Russia
}

\begin{abstract}
The article deals with the characteristics of religious discourse and peculiarities of religious consciousness; it is noted that religion and religious consciousness influence many constituents of culture and as a result of such influence religious philosophy, religious morality, religious art arise. Religious principle forms the basis of any culture. Main features and levels of religious consciousness realization are considered in the article. A large number of lexical units having religious origin and functioning in the language are evidence of the impact of religion on the culture formation. The impact of religion on the formation of culture is also manifested in common features of the normative base of a particular religion and culture in which it functions and the basis of which it forms.
\end{abstract}

\section{Introduction}

Culture represents a global system, a rather complicated "natural-artificial" formation. On the one hand, culture represents a living organism, because it reproduces itself, assimilates and processes the nature and surrounding world, reacts in a particular way to the impact of other cultures [1-5]. On the other hand, culture presents a result of people's activity which consists in aspiration to support traditions, to improve life and to confront traditions of destruction which can take place, etc.

"In the structure of linguistic personality a particular place is occupied by values - the most fundamental characteristics of culture, the highest reference points of behaviour" [6: 116].

\section{Methodology}

As far as culture represents a complicated and multifaceted phenomenon we can't confine ourselves to the only one definition of it. There exist different approaches to the interpretation of culture:

- descriptive (types of cultures are distinguished on the basis of differences in people's customs);

- anthropological (treat culture as aggregate of products of people's activity, world of things which opposes the world of nature);

- value (culture is a totality of material and spiritual values created by a human being);

- normative (culture is a set of norms and rules which regulate different aspects of life);

- adaptive (treat culture as a particular type of activity through which people adapt to the surrounding);
- historical (culture is treated as a product of history of the society, as experience which is passed from generation to generation);

- psychological (connect culture with people's psychology);

- didactic (define culture as a totality of experience acquired by people);

- sociological (treat culture as a factor of organization of public life, totality of ideas, principles, social institutions, which provide people's collective activity) [7].

We share the opinion of scholars working within the framework of value and normative approaches and define culture as a totality of created material and spiritual values, on the one hand, and set of norms and regulations which regulate different aspects of people's life, on the other.

Religion and religious consciousness influence actively on different components of culture, and as a result of it religious philosophy, religious morality and religious art appear. Religious moral imperative forms spiritual basis of the culture.

The main commandments which exist in any religion and build its moral basis then become main regulators of the culture of people which confess a certain religion and as a rule have common human origin. Mount Sermon of Jesus Christ has become a source of many moral postulates, for example.

\section{Results and discussion}

Analysis of referential structure of religious discourse allows us to distinguish a number of components: subjects of religion, religious trends, religious philosophy and religious actions. 
a. Category of subjects of religion is the main one and includes:

- religious institutions and their representatives:

church,

temple,

church

parish,

community,

monastery,

synagogue,

mosque

bishop,

archbishop,

metropolitan,

abbot,

rabbi,

mullah,

pastor,

deacon,

monk, etc.;

- agents of religion (different religious trends and their adherents):

Krishna and his doctrine,

Marmonism,

Bahaism

Hinduism,

Church of Christ

Hare Krishnas,

Buddhists,

Judaists,

Christians,

Islamists,

Bahaists,

Jehovah witnesses,

Marmons, etc.;

- religious anthroponyms - names of well-known religious figures:

Patriarch of Moscow and All Russia Alexey,

John Paul II,

Metropolitan of Volgograd and Kamyshin German,

Metropolitan of St. Petersburg and Ladoga Vladimir,

Metropolitan of St. Petersburg and Ladoga John, etc.

b. Religious systems and approaches:

Christianity,

Catholicism

Judaism

Islam,

Buddhism, etc.

c. Religious philosophy including religious values, principles and symbols:

faith,

brotherhood,

equality,

love,

prosperity,

appeasement,

spiritual freedom,

rescue,

immortal life, etc.

d. Religious actions:

praying,

confession, preaching,

psalmody,

baptizing,

ablution,

censing,

funeral service,

soboring,

crismation, etc. [8].

All elements of religion are closely related to culture, part of which they represent

The question about co-relation of religion and culture can't be resolved unequivocally. Some scholars are of the opinion that religion exists independently of culture though in some aspects it can influence it. According to the opinion of others, culture is a consequence of religion - culture presents lateral shoots of the cult [9]. We share the point of view of the researches who treat culture as a wider notion while religion is one of its constituent parts.

In contrast to people's culture, in general religious culture is a "totality of methods and techniques of providing and exercising of human's being which are realized in the process of religious activity, the center of which presents a cult" [10: 212].

Religious consciousness is inextricably linked with the belief in the supernatural. First of all what is linked with the belief in the supernatural are religious ideas, dogmatisms, and myths. Besides, each religion includes doctrinal, dogmatic or mythological elements which comprise the basis of religious consciousness.

Religious consciousness is comprised of two basic layers. Its basis is formed by religious philosophy which is a totality of ideas, points of view, ideas about the world and a person in it. The second layer of religious consciousness is formed by religious psychology which includes religious beliefs, feelings and spirits.

Religious consciousness is characterized by sensual presentation, imagery, combination of reality with illusions, faith, symbolism, dialogue character, strong emotional saturation.

Religious consciousness has two levels of realization: casual and conceptual. Casual religious consciousness is presented in the form of images, ideas, stereotypes, installations, mysteries, illusions, spirits, aspirations, directivity of will, habits and traditions which reflect conditions of people's life. On this level there are rational, emotional and volitional elements, though the dominant role is played by emotions and the content of consciousness is presented in visual-shaped form. Religious consciousness on the conceptual level is a systematized range of concepts and ideas. It includes:

1) doctrine about God (Gods), world, nature and a human being;

2) interpretation of the activity of different religious institutions functioning in the society, activity conducted in accordance with the principles of religious world outlook;

3) religious philosophy.

During person's socialization within this or that particular culture he acquires the definite cultural traditions. To certain extent both Russian and in many ways European cultures - are Biblical (Christian) cultures. 
A great number of Lexical units which generate from Holy Bible function in the Russian language and culture at present. Many of them have totally lost their religious shade, are no longer associated directly with the language of religion:

lawlessness,
nameless,

silence,

ugliness,

gratitude,

favourable,

nearest,

exclamation,

indignant,

memory,

apprehend,

hand over,

sonorous,

impudent,

goodness,

beauty,

longitude,

evil,

hefty,

amazement,

sincere,

strength,

wisdom,

population,

dwell,

denounce,

brunch,

feathered,

truth,

bickering,

the light,

treasures,

strange,

patience,

the crowd (plenty),

shelter,

generous.

"Bind up the testimony. Seal the law among my disciples» [11: 16-17].

Other lexical units keep connection with the religious sphere until this day, their functioning in the language and speech inevitably entails recreation of particular religious pictures and situations in the consciousness:

alleluia,

the altar,

greedy,

anathema,

angel,

godlessness,

evangelism,

grace,

piety,

shoving,

verb (Glagolitic),

to requite,

to love, to ascend,

revival,

burnt,

demon,

hand,

virtue,

Covenant

commandment,

Zenica,

sign,

idol,

Exodus,

repent,

ark,

meekness,

idol,

Messiah,

grace,

slander,

vow,

image,

finger,

flow,

cover,

vice,

parable,

Satan,

Cathedral,

creature,

darkness (a lot),

repast,

hope,

mouth,

womb, etc.:

"And now, Lord, what do I want for? My hope is in You. Deliver me from all my transgressions;

Do not make me the reproach of the foolish. I was mute, I did not open my mouth;

Because it was You who did it. Remove Your plague from me;

I am consumed by the blow of Your hand. When with rebukes You correct man iniquity. You make his beauty melt away like a moth;

Surely every man is vapor. Selah» [12: 7-11].

The indicator of Bible's impact on the Russian language and Russian culture is the fact that in the language, a lot of private names are taken from the Old Testament:

Ivan (Joann),

Mary,

Ann,

Gabriel,

Zachary,

Elizabeth,

Ilya,

Joseph,

Michael,

Semion,

Thomas,

$J a c o b$, etc. 
The names of a great number of personages from the Old Testament have been rethought many times and now function in the language as nominal ones:

Adam (primordial),

Belshazzar (Belshazzar feast - carefree pastime before some great trouble),

Elijah (Elijah the Prophet-long-suffering man),

Goga and Magog (something strange and ferocious),

Solomon (Solomon Court - bloody judgment; Solomon solution - right and wise decision, though rather cruel);

Judah (Judah's kiss - trying to preserve outward decency betraying somebody);

Noah (Noah's Ark - overcrowded room), etc.

The names of some personages from the Bible function as common nouns:

Judah,

Herod,

Chaldean,

Mary Magdalene, etc.

A great number of geographical names, which are mentioned in the Bible, have also enriched culture and have come into the Russian language as speaking ones:

Sodom and Gomorrah - focal spot;

Babylon - overcrowded and sinful city;

Babylonian pandemonium - a great many people which carry danger;

trumpet of Jericho - inappropriately loud voice, etc.

Bible has served as a source of many phraseological units:

each creature by pair,

to put in the forefront,

promised land,

tree of life,

a forbidden fruit,

root of evil,

manna of heaven,

flesh from the flesh,

a fig leaf,

do unto others as you want them to do to you,

a drop in the ocean,

to pass fire and water, etc.

The language of religion is characterized by the patterns of compositional decisions, interactivity, appellate character, and richness of speech resources.

"Religious texts must be organized in such a way that people who believe in God would except them as holy ones, perceiving preaching which they include and trying to follow them in their life" [13: 336].

The emergence of Christianity had a great influence on European culture [14-15]. The basis of Christian's picture of the world is formed by a number of dogmas: faith in one God, faith in the existence of afterlife world, faith in the Last Judgment and faith in resurrection of a man.

Christianity allowed people to look at the meaning of human's life from another angle. A person was recognized as the highest creation of God and which is more created "in the image of God". The highest religious goal had become the rescue which required faith and the definite spiritual efforts of a person. Christianity admits self-worth of a person.

Christian morality considers and accepts not external actions and external manifestations of faith but internal motivation of a person. Faith is based not on person's fear but on the overwhelming love both to God and to each separate person as a bearer of God's image.

Unlike Christianity in Buddhism there is no idea about Savior, there is no concept of God, there is no divine revelation, but there is a concept of the truth which bears features of everlasting substance existing in the world. In the center of attention is the idea of endless cycle. Along with this world there is another one - motionless and everlasting. Unlike any other religion in Buddhism person's destiny is conditioned by his own previous actions and thoughts (karma). There exists a world's order and a person must obey it. In the philosophy of Buddhism there is no death, but there is a chain of transformations in the circle of rebirths.

One more important idea of Buddhism is an idea of illusiveness of the surrounding and "reality of the unknowable absolute". The aim of life is to reach nirvana - such level of existence where all the sufferings are stopped. Nirvana in Sanskrit means 'slow extinguishing of fire'. Buddhism's teachings about salvation of man - is a teaching about possibility and methods to come closer to the highest knowledge - knowledge of the supreme truth. Due to the religion of Buddhism there are three levels of knowledge: ignorance (avidia - pre-logical consciousness), conceptual scientific knowledge (vidgnyana - logical knowledge), omniscience (pradgia above logical space knowledge).

Getting the knowledge of the truth by a man assumes shifting to the third level of knowledge, merging with the absolute.

According to the philosophy of Buddhism personality as such does not exist, what exists - is a succession of 'dhurms' of a person. Buddhists don't treat a personality as "something which starts from zero"; personality is a product of the space, it emerges from infinity and originally bears a potential of absolute perfection. What is originally laid in every personality is much more than finds manifestation in the real life of a person. Therefore, development of a personality suggests not "getting some new knowledge" but "deleting" of what is not necessary - cleaning consciousness from "dirty things".

The basis of Muslim culture forms Islam. The term "Islam" itself means "giving yourself to God, obedience". As in any other religion, faith is very important in Islam, but on the other hand, Muslim religious culture appreciates knowledge. Ethics of the Muslim culture is based on the unity of knowledge, faith and action. The virtues of Islam include mind, modesty, and fear of God, righteousness, fidelity, sincerity, humility, forgiveness, and absence of anger. The idea of divine predestination is developed in Islam to a greater extent than in Christianity.

\section{Conclusion}

Thus, religious consciousness and the definite religious philosophy, which functions in the definite society, 
predetermines and forms the culture of a particular society. Religion helps to support and develop cultural traditions; presents moral guidelines of behavior, formulates the main values of a particular cultural society; stabilizes spiritual life of the members of society; levels the significance of claims for creature comforts, denies their importance and gives priority to the comforts of the future life.

\section{References}

1. E.V. Bobyreva, O.A. Dmitrieva, M.R. Zheltukhina, M.V. Busygina, Proceedings of the 7th International Scientific and Practical Conference Current Issues of Linguistics and Didactics: The Interdisciplinary Approach in Humanities (CILDIAH 2017). ASSEHR 97, 52-56. (2017)

2. V.I. Karasik, Collection of papers, 3-16 (1996)

3. P. Florenskiy, Philosophy of the cult (Mysl, Moscow, 2004)

4. V.I. Karasik, Intergollegiate collection of papers, 519 (1999) 7

5. D.Yu. Gulinov, M.R. Zheltukhina, L.A. Shestak, G.G. Slyshkin, V.V. Katermina, L.D. Chervyakova. Modern Journal of Language Teaching Methods 8 (2), 159-173 (2018)

6. V.I. Karasik, Linguistic circle: personality, concepts, discourse (Peremena, Volgograd 2002).

7. A.S. Karmim, E.S. Novikova, Culturology (Piter, St.Pt., 2006)

8. E.V. Bobyreva, Religious discourse: values, genres, linguistic characteristics (on the basis of Orthodox religion) (Peremena, Volgograd, 2007)

9. E.V. Bobyreva, Religious discourse: values, genres, linguistic characteristics (on the basis of Orthodox religion) (Peremena, Volgograd, 2007)

10. I.N. Yablokov, Religious studies (Gardariky, Moscow, 2004) 10

11. Bible: Books of Scripture of Old and New Testament. Isaiah 8 (Brussels: Experience with God, 1973) 1

12. Bible: Books of Scripture of Old and New Testament. Psalms 39 (Brussels: Experience with God, 1973) 2

13. M. Voytak, Stereotype and art: Intercollegiate collection of papers 6, 323-339, (2003)

14. N. Davis, O. Ergunova, V. Lizunkov, E. Malushko, European Proceedings of Social and Behavioural Sciences 26, 550-556 (2017)

15. E. Yu. Malushko, International Multidisciplinary Scientific Conferences on Social Sciences and Arts, 1155-1160 (2015) 